\title{
The Market Reaction to Legal Shocks and Their Antidotes: Lessons from the Sovereign Debt Market
}

\author{
Michael Bradley, James D. Cox, and Mitu Gulati
}

\begin{abstract}
In September 2000, a Brussels court ruled in favor of a hedge fund that held an unpaid debt claim against the Republic of Peru. The decision was based on a novel interpretation of the common pari passu clause. Policy makers and practitioners suggested that this decision signaled a paradigm shift that caused a significant increase in the risk of holdout litigation faced by sovereign debtors. Over the ensuing years, multiple reform solutions were implemented including the revision of certain contractual terms, the filing of amicus briefs in a key New York case, and the passage of legislation in Belgium. This article investigates whether the markets perceived an increase in risk in sovereign debt in the wake of the Brussels court decision. And, to the extent the markets reacted to the increase in legal risk, did any of the antidotes that were implemented to reduce the supposed increased holdout risk work?
\end{abstract}

\section{INTRODUCTION}

This article examines the market reaction to a series of legal events concerning the judicial interpretation of the pari passu clause in sov-

Michael BRAdley is the F.M. Kirby Professor of Law and Finance at Duke University. JAMES D. COX is the Brainerd Currie Professor of Law at Duke University. Mitu gulati is Professor of Law at Duke University. Thanks to Stephen Choi, Anna Gelpern, Lee Buchheit, Marcel Kahan, Kim Krawiec, Tom Miles, Eric Posner, Mark Ramseyer, Barak Richman, Robert Scott, and workshop participants at the Institute for Law and Finance (University of Frankfurt) for comments and conversations about this project. Special thanks to an anonymous referee for comments that helped sharpen our analysis considerably. Finally, we thank Dong Chen and Congcong Li for excellent research assistance. Disclosure: One of authors (Gulati) worked as an expert on a litigation involving the pari passu clause that occurred subsequent to the case that is at the center of this article.

[Journal of Legal Studies, vol. 39 (January 2010)]

(C) 2010 by The University of Chicago. All rights reserved. 0047-2530/2010/3901-0008 $\$ 10.00$ 
ereign debt instruments. ${ }^{1}$ More generally, the article provides insights into the reactions of investors (predominantly financial institutions), issuers (sovereigns), and those who draft bond covenants (lawyers) to unanticipated changes in the judicial interpretation of certain covenant terms.

The first event-the initial shock-occurred in September 2000, when a Brussels court, ruling in Elliott v. Peru (Elliott Assocs. No. 2000/QR/ 92 [Court of Appeals of Brussels, 8th Chamber, September 26, 2000]), granted the hedge fund Elliott Associates (hereafter, Elliott) an injunction against Peru, prohibiting it from paying its favored creditors unless pro rata payments were made to all the creditors who ranked pari passu according to the terms of their contracts. ${ }^{2}$ Concerned that the injunction would force it to default on its obligations, Peru settled with the holdouts for upwards of $\$ 55$ million-a tidy profit in view of the fact that Elliott had earlier purchased the bonds for approximately \$11 million (for descriptions of the case and the furor it caused, see, for example, Salmon [2004]; Berry [2006]; Bratton [2004]).

\subsection{Background}

The injunction that was granted in Brussels in September 2000 was the culmination of creditor litigation against the Republic of Peru that had

1. Pari passu terms are ubiquitous in sovereign debt issuances and more generally in cross-border transactions. See Buchheit and Pam (2004, p. 871). Buchheit and Pam, two practicing lawyers in the sovereign debt field, explain these clauses at the outset of their article: "Here is a typical formulation of the pari passu clause in a modern cross-border credit instrument: 'The Notes rank, and will rank, pari passu in right of payment with all other present and future unsecured and unsubordinated External Indebtedness of the Issuer.' The Latin phrase pari passu means 'in equal step' or just 'equally.' The phrase pari passu was often used in equity jurisprudence to express the ratable interest of parties in the disposition of equitable assets. As explained by an English commentator in 1900: 'There is no special virtue in the words "pari passu," "equally" would have the same effect, or any other words showing that the [debt instruments] were intended to stand on the same level footing without preference or priority among themselves, but the words pari passu are adopted as a general term well recognized in the administration of assets in courts of equity"' (Buchheit and Pam 2004, p. 871, quoting Francis B. Palmer Company Precedents [1900, pp. 109-10]). In our data set of over 300 issuances, every offering document contained a pari passu clause. Further, as if to indicate its great importance, a version of the pari passu clause often showed up on the cover page of the offering document and most of the time was one of the terms described in the "summary of key terms" section at the front of the offering document. See also Choi and Gulati (2006, p. 1134 and n.12)

2. The favored creditors at the time were the holders of Peru's Brady bonds. These were the creditors who had entered into a restructuring agreement with Peru and taken the Brady instruments in exchange for their old bonds. Only a handful of creditors did not enter the exchange. Elliott was holding some of the paper that was not submitted in that exchange. The one other creditor that appears to have rejected the Brady exchange was Pravin Banker. 
started some years earlier in another case, Pravin Banker v. Banco Popular del Peru (see Wheeler and Attaran 2003). Banco Popular, a stateowned commercial bank, had stopped making payments on its principal in the wake of Peru's financial crisis in 1983. Pravin Banker purchased a small amount of Peruvian foreign debt in the secondary market in 1990. Subsequently, it refused to participate in the liquidation process of Banco Popular that followed. Instead, it sued both Banco Popular and Peru, the guarantor of the debt, in federal court in New York (Wheeler and Attaran 2003, pp. 267-68). Peru's primary defense was based on the notion of international comity. Comity is a doctrine that allows U.S. courts to defer to the policies of a foreign government if those policies do not conflict with U.S. interests. Peru argued that its efforts to achieve an orderly restructuring under the Brady Plan not only advanced its interests but was consistent with the broader International Monetary Fund (IMF) and U.S. policies aimed at establishing stability in the international financial system. ${ }^{3}$ Pravin Banker countered that contractually it was not obligated to enter into the restructuring. Since the parties had designated New York law to govern the indenture, New York itself had an interest in enforcing the terms of contracts as written. To do otherwise would, Pravin Banker argued, introduce uncertainty into the contracts and undermine New York's ability to attract business. Initially, the district court appeared sympathetic to Peru's interests in achieving a successful restructuring and granted multiple stays. Ultimately, however, the court's patience ran out, and it ruled against Peru (Wheeler and Attaran 2003, pp. 267-68; Pravin Banker, 895 F. Supp. 660, 668 [S.D.N.Y. 1995]). On appeal, the Second Circuit rejected Peru's comity defense, deferring instead to what the court saw as the broader interests in enforcing contract provisions (Pravin Banker, 109 F.3d 850, 856 [2d Cir. 1997]). The holdout victory by Pravin Banker was a hollow one. Winning a judgment against a sovereign means little unless it can be enforced. Meaningful enforcement of its victory required some mechanism by which its judgment could enable the creditor to seize Peruvian assets. Since there were few Peruvian assets in New York, the focus of

3. The Brady Plan, named after U.S. Treasury Secretary Nicholas Brady, was a U.S.driven plan to reduce developing-country debts to Western banks by exchanging bank loans for tradable bonds with long maturities or reduced principal amounts. Some new bonds were collateralized with U.S. Treasury securities. In early Brady restructurings, the collateral was purchased with funds from multilateral institutions. The Brady Plan is generally credited with restarting the emerging-market bond market after a hiatus of over half a century. See Buckley (1998). 
the creditor-holdout's litigation efforts shifted, resulting in the subsequent Elliott litigation.

The Elliott litigation against Peru began a few years later, also in federal court in New York. Like Pravin Banker, Elliott had purchased Peruvian debt at a discount in the secondary market and had also refused to enter into the Brady restructuring (Wheeler and Attaran 2003, pp. 257-58). Having earlier lost on comity, Peru's defense this time was that the litigation violated New York's champerty law (N.Y. Jud. Ct. Acts sec. 489 [McKinney 1983]). Champerty is an old New York doctrine aimed at deterring the use of litigation as a harassment technique. Under this doctrine, courts will not recognize claims brought by those who had purchased them with "the intent and purpose of bringing an action or proceeding thereon" (Elliott Assocs. v. Banco de la Nacion, 12 F. Supp. 2d 328, 332 [S.D.N.Y. 1998]). The district court agreed with Peru's defense and dismissed the suit (12 F. Supp. 2d 328, 332). However, on appeal, the Second Circuit reversed, rejecting Peru's champerty defense and reaffirming its prior policy of requiring contract terms to be enforced. The Second Circuit reasoned that because Elliott's primary objective was to recover the full value of its debt claims, champerty was not present, since the lawsuit was merely incidental to achieving that legitimate goal (Elliott Assocs. v. Banco de la Nacion, 194 F.3d 363, 378 [2d Cir. 1999]).

The question that remained, however, was how to enforce the judgment against Peru. Elliott sought to reap the benefits of its victory by pursuing attachment orders against the payments Peru was attempting to make on its newly restructured Brady bonds. Elliott therefore sought attachment orders in multiple jurisdictions, including the United States, Canada, Belgium, the Netherlands, Luxemburg, England, and Germany (Olivares-Canal 2009). On remand from the Second Circuit, the district court in New York issued an attachment order against Peru for upwards of $\$ 55$ million (see Elliott Assocs. v. Banco de la Nacion, 194 F.R.D. 116, 117 [S.D.N.Y. 2000]; Elliott Assocs. v. Banco de la Nacion, No. 96 Civ. 7916, 2000 U.S. Dist. LEXIS 14169, at *1 [S.D.N.Y. September 29, 2000]). The attachment orders had the effect of restricting Chase, the fiscal agent on the Brady bonds, from transferring payments to the bondholders (Wheeler and Attaran 2003, p. 258). To bypass the risk of attachment in New York, Peru sought to use Euroclear, in Brussels, to make the planned payments. But Elliott had filed an attachment order there as well. And although the initial request for the ex parte injunction in Brussels was denied, the Court of Appeals reversed and granted the 
injunction (Elliott Assocs., No. 2000/QR/92 [Court of Appeals of Brussels, 8th Chamber Belgium, September 26, 2000]). At this point, Peru faced the risk of defaulting on its Brady bonds, which in turn would have triggered cross-default provisions and accelerations in its other bonds (International Monetary Fund 2001, p. 48). To avoid this sequence of events, Peru paid Elliott $\$ 56.3$ million in an out-of-court settlement. Elliott's holdout strategy thus rewarded it with a handsome profit.

\subsection{Implications and Impact}

Elliott was important for two reasons. First, it represented the first time a holdout creditor had effectively used a litigation strategy to extract a disproportionate payment out of a sovereign. Holdouts had been suing sovereigns for some time, but until Elliott, their enforcement strategies had largely amounted to an annoyance strategy. Sovereigns had been able to avoid attachments of significant portions of their assets. Elliott changed that. Second, the strategy that had worked, which urged a particular interpretation of the pari passu clause, potentially altered the risks for every sovereign bond outstanding, since the pari passu clause is included in all sovereign bond issues.

The decision had the potential for disrupting the international flow of funds. As noted, prior to Elliott, international creditors facing a defaulting sovereign debtor had no legally enforceable option for gaining bargaining power vis-à-vis the debtor or rival holders (Gulati and Klee 2001). ${ }^{4}$ Prior to Elliott, the pari passu clause seemed largely meaningless and, hence, harmless in the context of sovereign debt instruments. Outside the sovereign debt offering, the pari passu clause bars nonproportional payments among creditors in the liquidation of the debtor's estate. Since sovereigns cannot liquidate, it was unclear to even the leading commentators at the time what the function of the pari passu clause was in the sovereign context (Wood 1995, p. 165; Buchheit 1991, pp. 11-12).

Elliott alerted the market to two significant risks, one general and

4. There is a good deal of evidence of market participants characterizing Elliott Associates as both unexpected and seismic. See, for example, Zarin $(2000$, p. 1$)$, in which a Moody's analyst observes, "[I]t turns [the investor's] suit from an academic and avenging 'I told you so' option to a more lethal weapon," and Lindenbaum and Duran (2000, p. 4): "Elliott Associates' successful litigation against Peru . . . importantly set a precedent for the attachment of bond coupons. This could increase the incentive to hold out in debt restructurings." 
the other specific. First, it was feared that hedge funds were going to be aggressively policing contract language, making innovative arguments about the meaning of ambiguous clauses and using those arguments to seek attachment orders. ${ }^{5}$ Second, as a result of Elliott, these funds now had a potent weapon, the pari passu clause. Elliott had given the pari passu clause legal significance by empowering creditors to invoke the clause as a means of holding up sovereign debt restructurings. This was a bargaining chip that heretofore was not possessed by the holders of sovereign debt.

Elliott caused consternation among government officials and bond market participants (Panizza, Sturzenegger, and Zettelmeyer 2009). As later argued by the U.S. Treasury, the N.Y. Federal Reserve, and the New York Clearing House, ${ }^{6}$ the widespread acceptance of the interpretation of the pari passu clause provided by the Brussels court (the "rateable payments" interpretation) would not only exacerbate the classic holdout problem associated with debt but would wreak havoc with the international flow of funds between countries and their creditors. The rateable payments interpretation would require a sovereign to pay all its creditors on a pro rata basis if it decided to pay any creditor anything. At the least, the country would have to stand ready to pay off all of its creditors on a pro rata basis if the creditors so desired. Since a debtor nation could be required to pay all creditors if it attempted to pay any one creditor, pari passu clauses give every creditor significant power over the sovereign's ability to deal with its creditors on a one-to-one basis.

The ability of any one bondholder to hold up an efficient reorganization of the debt of sovereign issuers injected new risk into these securities. The net effect of enforcing such clauses would be to preclude efficient reorganizations and render repayment more risky because of the reluctance of the debtor to repay anyone unless it was prepared to

5. A similar paradigm shift has been observed in the corporate bond areas (where Elliott has also been one of the players). See Kahan and Rock (2008).

6. The New York Clearing House is an association of the some of the largest commercial banks in the United States including the Bank of America, Citibank, and HSBC. For details, see The Clearing House, TCH Board (http://www.theclearinghouse.org/about/ board/000215f.php). The filing of an amicus brief disagreeing with Elliott's rateable payments interpretation was potentially important in terms of showing a judge that it was not just the sovereign debtors who thought that Elliott's interpretation was destructive but also all the major creditors. Senior lawyers at Sullivan \& Cromwell, the law firm that does the largest share of work for underwriters doing sovereign issuances, were the authors of the brief for the Clearing House (Brief in Macrotecnic Int'l Corp. v. Republic of Argentina, No. 02CV-5932 [S.D.N.Y. January 12, 2004] [http://www.theclearinghouse.org/reference/amicus_ curiae/index.php]). 
pay everyone. In addition to the specific risk of increased holdout litigation via the pari passu clause, there was also the broader risk that holdout creditors, particularly opportunistic hedge funds, emboldened by the enormous success of Elliott, were going search for, and find, other techniques of enforcing judgments against sovereigns.

Consistent with the above concerns, the post-Elliott period has seen both the pari passu argument raised opportunistically in a number of cases and the use of other innovative strategies to enforce a party's bargaining power against defaulting sovereigns. ${ }^{7}$ While sovereigns have succeeded in defending some of these cases, they have had to settle others.

Our interest here is in the impact of the heightened risk of holdout litigation that Elliott signaled, if not caused directly. Presumably, the impediments to efficient reorganizations and the ability of certain bondholders to extract rents from either sovereigns or other bondholders would be priced by capital market participants, resulting in a higher required rate of return on sovereign debt. This, in part, is what we seek to determine in this study.

\subsection{Antidotes}

In an attempt to reduce the new set of uncertainties signaled by Elliott, sovereigns began to adopt a particular type of contractual provision called a collective action clause, or CAC. ${ }^{8}$ The vast majority of sovereign debt is held by institutions and other large investors around the world. The prior norm in the New York market had been that the payment terms of a bond could be modified only with unanimous approval of the holders of that issue. As a result, each bondholder held a potential veto over any restructuring attempt. This potential veto inherently invites holdouts to engage in strategies of the type successfully employed in Elliott. At the time, the U.S. government perceived the inclusion of CACs in sovereign debt instruments to be an antidote to the holdout problems

7. For discussions of these cases and the strategies used, see Olivares-Canal (2009), which discusses at least two cases involving the Congo's unpaid debt brought in the United States, Red Mountain Financial v. Democratic Republic of Congo and Kensington International $v$. BNP Paribas, where holdouts using pari passu arguments were able to extract settlements. See also Berry (2006) and Lippert (2008).

8. A collective action clause $(\mathrm{CAC})$ is a covenant written into a bond contract that allows a prespecified fraction of the firm's bondholders to alter the payment terms of the contract (principal, interest, and dates of payment); without a CAC, any change in the terms of the indenture agreement must be approved by all of the firm's bondholders. Thus, the effect of a CAC is to reduce the holdout problem associated with a unanimity rule and should therefore reduce the spread on sovereign debt. See Gelpern and Gulati (2006). 
296 / THE JOURNAL OF LEGAL STUdies / VOLUME 39 (1) / JANUARY 2010

signaled by the Elliott episode. Most CACs replace the unanimity rule with a requirement that the affirmation of only 75 percent of the holders in principal amount is needed to modify the terms of a debt contract. By dropping the required approval percentage from 100 percent to 75 percent, CACs reduce somewhat the opportunity for holdouts to disrupt bond restructurings.

Note, however, that CACs do not directly get at the specific holdout litigation problem posed by Elliott's rateable payments argument. Elliott in fact creates an ex post problem since its ill effects occur after a restructuring has begun. Collective action clauses instead work to protect against the broader holdout problem in the restructuring itself in that a single bondholder can no longer hold up a restructuring agreement; with CACs, more than 25 percent of the holders in the principal amount are needed to veto a restructuring. The two problems are related, however, in that the holdout litigation problem can occur only if a bondholder can avoid being forced into a restructuring. A more significant problem with the CAC "solution" is that the typical CAC applies to only a single bond issue. A creditor wanting to hold out could still do so by buying bonds from a prior issue by the sovereign that do not contain CACs, refusing to enter the restructuring, and invoking the pari passu clause once the postrestructuring payments had begun. For the CAC solution to work effectively, sovereigns would have had to go beyond incorporating CACs into their new bonds, as Mexico did in February 2003. They would also have to do an exchange of all their outstanding nonCAC bonds for new CAC bonds, thus ameliorating the threat posed by the rateable payments interpretation. Sovereigns, however, were simply not willing to pursue this course of action, suggesting therefore that including CACs in sovereign debt agreements might not have been the antidote they were anticipated to be, if they were an antidote at all (Bratton and Gulati 2004).

Collective action clauses suddenly appeared in sovereign debt contracts in early 2003. Collective action clauses were largely unheard of in the U.S. market before 2003, although they had long been used in sovereign bonds issued in the UK market. Between 2001 and 2003, the U.S. Treasury, under the stewardship of Undersecretary John Taylor, mounted a campaign to persuade players in the U.S. sovereign debt market to adopt CACs as an antidote to the holdout problem exemplified by cases such as Elliott. ${ }^{9}$ Beginning in February 2003 with Mexico's

9. The process by which Elliott's success against Peru pushed John Taylor toward 
adoption of these clauses, sovereigns quickly began adopting CACseven though practitioners continued to express skepticism as to whether the adoption of these clauses provided a meaningful solution to the holdout problem (it was, some said, a means of appeasing the U.S. government; Gelpern and Gulati 2006). We offer empirical evidence of the market's assessment of whether CACs impact the riskiness of bonds.

Available data demonstrate the success the U.S. government had with its campaign to encourage the adoption of CACs: among 181 observations before 2003, only 7 (4 percent) contained a CAC; of the 129 observations after 2003, 111 (86 percent) included a CAC. The adoption of CACs was explicitly intended as a response to the holdout creditor threat exemplified and amplified by Elliott (Gelpern and Gulati 2006). Thus Elliott arguably stimulated the widespread adoption of a perceived contract solution (antidote), CACs, to the holdout problem.

A second potential antidote to the uncertainties created by Elliott occurred in January 2004, when the U.S. government announced its position repudiating the wisdom of that decision through amicus briefs filed in ongoing litigation in New York involving debt issued by Argentina. ${ }^{10}$ In these briefs, the U.S. Department of Justice (writing based on the advice of the Treasury Department) and the New York Federal Reserve argued against the rateable payments interpretation of pari passu clauses, reasoning that such a construction would exacerbate the holdout

advocating the CAC solution was via the International Monetary Fund's (IMF's) proposal for an international bankruptcy regime for sovereigns (the SDRM). Elliott's success was key in persuading IMF Deputy Director Anne Krueger that the risk of holdout creditors had risen to a level that a global solution needed to be implemented. She proposed the SDRM, and the Elliott problem featured prominently in her speeches explaining why the SDRM was needed. See Krueger (2001). Taylor, favoring a more market-driven solution, countered by urging contractual reform as an alternative solution. The specific contractual reform proposed was the CAC. Eventually, the CAC solution won out over the SDRM. See Gelpern and Gulati (2006), which describes the CAC-SDRM competition. On the success of the CAC solution, see Economist's View (2006), which observes that the drop in spreads occurred in conjunction with the widespread adoption of CACs. See also Taylor (2008, pp. 29-30), which characterizes 2003 as the "Year of the Clauses" and one of the big successes of the George Bush-appointed Treasury team.

10. Statement of Interest of the United States, at 5-6, and Memorandum of Law of Amicus Curiae, Federal Reserve Bank of New York, at 5-6, Macrotecnic, No. 02-CV-5932 (S.D.N.Y. January 12, 2004), which states that the adoption of the wide interpretation of the pari passu clause "would allow holdout creditors to disrupt the efficient operation of payment and settlement systems, create legal uncertainty for those systems, and ultimately cause adverse economic implications for beyond the sovereign debt dispute." 
problem whenever a sovereign sought to renegotiate its debt. ${ }^{11}$ In light of the fact that the U.S. government rarely intervenes in sovereign debt disputes and that courts are reputed to take the U.S. government's views seriously when it does, the filings of the briefs constituted major events. ${ }^{12}$ Adding to this, in response to new litigation over the pari passu clause in Brussels, the Belgian legislature passed legislation in December 2004 that made it harder for the holdouts to employ the strategy used in Elliott. $^{13}$

The amicus briefs filed on behalf of the defendant in the New York litigation, combined with the actions of the Belgian legislature, presumably sent a signal to participants in the sovereign debt market that the official sector (the Group of Eight governments, their finance ministries, and the major international financial organizations) disfavored the rateable payments interpretation of the pari passu clause (Mondino, Medrano, and Laspina 2003). The 2004 governmental responses were likely to impact any court faced with a holdout creditor raising the rateable payments interpretation. In addition, in early 2005 , a group of eminent English lawyers added its view to the general position disfavoring the rateable payments interpretation. Although the expert group was put together under the auspices of the Bank of England, this report was not an official statement of the UK government. Nevertheless, it likely gave sovereigns additional confidence that the weight of authority was against the rateable payments interpretation (Financial Markets Law Committee 2005). In other words, after 2004, one might expect that countries could

11. As noted earlier, the New York Clearing House, which represents the largest commercial banks, also filed a brief in the case, taking the same position as the U.S. government. See amicus curiae brief, New York Clearing House, Macrotecnic, No. 02-CV-5932 (S.D.N.Y. January 12, 2004). Elliott also sparked a flurry of concern at the IMF. The IMF focused on the implications of the Brussels' court decision for the creditors of countries that default on their debt. The result of this concern was a formal proposal for an international bankruptcy court, which would among other things have the power to reform contract terms and grant stays on litigation-similar to the stay associated with Chapter 11 in the United States. The purpose, in light of Elliott, was to give defaulting countries the time to work out their finances in an orderly fashion and, presumably, to insure that pari passu clauses and other provisions were properly enforced. See Hagan (2005).

12. Domestic U.S. courts are generally seen as giving the highest levels of deference to the U.S. government's views in cases involving foreign affairs. See Eskridge and Baer (2008); compare Scott (2006, p. 10), which describes Elliott as the "highwater mark for creditor's rights" and criticizing the U.S. government for stepping in and curtailing those rights.

13. For discussion, see National Bank of Belgium (2005) and Werning (2005), which reports on the view that the Belgian legislation had reduced the litigation risks posed by holdouts such as Elliott. 
feel safer dealing with one creditor at a time without having to deal with all creditors pro ratably because of a pari passu clause. ${ }^{14}$ More broadly, the 2004 governmental responses may have also sent a signal to the market that the official sector was willing to intervene in litigations against holdouts trying to disrupt sovereign restructurings—signaling a policy position contrary to that taken by the Second Circuit in Pravin Banker. Pursuant to this view, we conjecture that after 2004 sovereign debt became less risky and the market more liquid, which presumably increased the value of sovereign debt and reduced the required rate of return demanded by investors. Subsequently, we examine whether these actions impacted the required return on sovereign debt offerings.

The primary question that this article asks is whether traders in the sovereign debt market acted in a predictable fashion in response to these regime shifts both in the legal interpretation of pari passu clauses and in official sector policy regarding holdout litigation. An ancillary question is the extent to which the legal counsel of sovereign debt issuers felt compelled to rewrite the language in pari passu clauses in order to reduce the uncertainties injected by Elliott.

Assuming that capital market agents incorporate the implications of important events into the pricing of securities, we ask whether the market considered these legal events to be significant. That is, did prices move accordingly? Specifically, we inquire whether the markets perceived a significant increase in the risk of holdout litigation subsequent to Elliott (the shock) and if they subsequently perceived that the move to CACs, the filing of briefs by the official sector and the passage of legislation in Belgium, provided antidotes to the holdout problem exacerbated by $\mathrm{El}$ liott.

In the sovereign debt literature, there is speculation in both directions. Some have suggested that the risk of holdout litigation was never significant (Roubini 2004, pp. 126-27). Perhaps the holdout risk was exaggerated by those in the official sector to serve political and bureaucratic goals such as the creation of a new International Bankruptcy Court under the auspices of the IMF (the "cynical story")? A recent study of participants in the sovereign debt market reports a number of the players as

14. A recent article by one of the primary sovereign-side litigators points to two specific antidotes, the filing of the amicus briefs and the Belgian legislation (but not to CACs), as being among the primary factors in eliminating the Elliott-type pari passu litigation threat by roughly the end of 2004 (Blackman and Mukhi, forthcoming). 
saying that the official sector had been galvanized to solve a holdout problem that was minimal at best. ${ }^{15}$

Alternatively, the official sector version of the story (the "official story") contends that the holdout risk, particularly in the wake of Elliott, was significant and raised the costs of default. ${ }^{16}$ Not surprisingly, the official story goes on to claim that the holdout antidote that it pushed most aggressively, CACs, ameliorated the risk of holdouts and importantly, for our purposes, reduced the required returns to sovereign debt (Economist's View 2006). Even within the context of the official story, however, there is the question of which of the different strategies undertaken by the official sector-the narrower antilitigation defense strategy that involved the filing of amicus briefs and the passage of legislation or the broader contractual reform strategy that involved persuading private parties to reform their contract provisions-worked best to ameliorate the holdout threat that had arguably been elevated from minor nuisance to major crisis by Elliott (Sturzenegger and Zettelmeyer 2007). To date, there has been no empirical inquiry into this question. ${ }^{17}$

To foreshadow the formal presentation of the results of our empirical analyses, we find that the average spread on sovereign debt-defined as the difference between the yield to maturity on a bond when issued and the yield to maturity of a U.S. Treasury bond with the closest time to maturity-increased significantly in the wake of Elliott and decreased significantly after the New York litigation (the filing of the amicus briefs) and the Belgian legislation. In other words, we do not find support for the cynical story. Instead, we find support for the hypothesis that the markets perceived an increase in the risk of holdout litigation. We also find support for the hypothesis that some of the steps taken by the official

15. One player observed, "Suing a sovereign is so damn hard-being a holdout is hard, not smart. . . . [T] he official sector was offended by what happened to Peru-someone bought low and shook down Peru. . . . It offended [their] sense of fairness in the financial system" (Gelpern and Gulati [2006, p. 1693], which reports on interviews with leading market participants).

16. This view was articulated by Stanley Fisher in his Lionel Robbins Lectures on the International Financial System, where he asserted that "[r]ightly or wrongly, debtor governments see the costs of default as extremely large-and recent legal developments, including the Elliott Associates case in the Peruvian debt restructuring, have raised the likely costs." See Kumar and Miller (2003, p. 351), which quotes Fisher's lecture and articulates the view of increased litigation risks as a result of holdout creditors.

17. The treatment that comes closest to analyzing this question looks at a series of case studies of recent restructurings and suggests, on the basis of the higher than normal settlement amounts there, that the cause of those higher amounts might be the enhanced risk of holdout litigation (Kumar and Miller 2003). 
sector (the official story) helped ameliorate the holdout risk. However, there is only partial support for the official story. We find that CACs, an innovation in contract language advocated by the U.S. Treasury to ameliorate the holdout problem and the antidote most often emphasized in the telling of the official story, did not help to reduce spreads. In other words, the portion of the official sector strategy that focused directly on litigation to negate the pari passu argument worked to reduce the required return on sovereign debt. But the broader strategy of the U.S. government of promoting a contract clause that ameliorated holdout problems, the CAC, had little impact on the pricing of sovereign debt.

Our results help answer the question of whether pricing in the sovereign bond market is sensitive to litigation and contractual reform. The empirical studies on the sovereign market to date have all looked at the effects of one particular type of contract provision, the CAC, on pricing. Some of the studies find no pricing effects of CACs, whereas others do. A critical limitation of these studies is that they were all conducted prior to 2003, when the big shift toward CACs occurred in the U.S. marketthese studies often compare UK bonds, which typically include CACs, with U.S. bonds without CACs (Dixon and Wall 2000; Becker, Richards, and Thaicharoen 2003; Gugiatti and Richards 2003; Eichengreen and Mody 2000a and 2000b). By contrast, because of the extensive and more recent data set that we use, our study is able to examine the effects of using CACs within a single market, the United States. Further, prior studies do not correct for variations in the types of clauses-that is, variation in the phrasing of the clauses that might affect the legal risk. ${ }^{18}$ Instead, for the most part, it is simply assumed that bonds governed by UK law had CACs and those governed by U.S. law did not-itself problematic since some U.S. bonds issued prior to 2003 did have CACsand that all CACs and non-CACs were identical. ${ }^{19}$ The problem, however, is that the CACs and non-CACs being examined in all of these studies likely had significant variation in phrasing that would have af-

18. For more on the differential vulnerability to holdout creditor risk as a function of variations in the language of the clauses, see Choi and Gulati (2004).

19. Indeed, among the handful of sovereign bonds that were issued in the late 1970s and early 1980s, in both the United Kingdom and the United States, we have found some issuances with an absence of any contractual language dealing with the collective action issue. Since these bonds were not in the database we used for this study, however, they are not included in our empirical analysis. 
fected legal risk (Choi and Gulati 2004). ${ }^{20}$ Our study endeavors to adjust for specific phrasing and its impact on litigation risk. Consistent with research on corporate bonds, we find that sovereign bond pricing is sensitive to changes in legal risk posed by a particular type of bond covenants. ${ }^{21}$

\section{EMPIRICAL DESIGN}

Evaluating whether market prices react to legal changes-such as court decisions or the passage of legislation-is typically difficult because it is rarely clear whether the final court decision or passage of legislation was anticipated and its likely effects incorporated into the price of the firm's securities long before the legislation became official or the court decision became public. To correct for such problems, researchers typically estimate windows of time during which the legal event might have begun to be anticipated (Bhagat and Romano 2002). ${ }^{22}$

Elliott, however, presents a unique natural experiment in which the court's decision came as a shock to the market and was clearly unanticipated. The decision granting the injunction was made ex parte on the basis of submissions from Elliott alone. Had Peru not settled the case so quickly, Peru's lawyers would have been able to make their arguments before the court and a different result might have eventuated. But Peru's heightened need to settle-reportedly a function of President Alberto Fujimori's tenuous political position and resultant desire to avoid the publicity that a default on Peru's Brady bonds might have brought—was also likely unanticipated (Scott and Gulati 2010).

We think that it is plausible to assume that the filing of the government briefs in early 2004 was also largely unanticipated by the market. We say this not only because the adversarial nature of the litigation

20. Our study did not have to confront the problem of differing forms of CACs since the language of the CACs in our study was strikingly similar, with no material differences in their content.

21. For example, Bradley and Roberts (2004) finds that covenants in corporate bonds are priced by capital market participants.

22. With respect to judicial decisions, Bhagat and Romano (2002, p. 393) note that "judicial decisions are not clearly 'events' except for the litigants . . . [because] other firms and investors will be able to contract around a rule and recalibrate costs and benefits." However, in the instant case, Elliott did not resolve any issue that firms could subsequently contract around. Rather the decision injected uncertainty in the pricing of sovereign debt. Further, as discussed later, the data show that the lawyers found themselves unable to contract around the decision. 
process means that the substance of the briefs would have been kept secret until the last moment but also because it was not clear what the U.S. government's position was going to be. Because in prominent prior sovereign disputes the United States had taken the position that New York courts should not interfere in matters of contract interpretation, it was possible that the United States would be reluctant to say much of anything with respect to the contract interpretation issue (see Fisch and Gentile [2004, p. 1079], which discusses the Allied Bank set of cases and the U.S. government's position there). ${ }^{23}$ The Belgian legislative decision, by contrast, was likely anticipated much before it happened. The legislative process typically entails a good deal of negotiation and deliberation over many months, if not years. This was very much the case with the Belgian legislation. ${ }^{24}$ As an approximation, therefore, we assume that the markets knew about the impending legislation in early 2004. Much the same can probably be said about the report prepared by the expert group in the United Kingdom in 2005-given that the group was made up of eminent lawyers from the largest players in the sovereign markets, it is likely that the impending release of the report and its message were anticipated well before it became public knowledge. Thus, while we suspect that the filing of the amicus briefs in early 2004 was not expected, and therefore likely had an effect on yields, there were also subsequent events pushing in the same direction that should have had further impact on yields over the 2004-5 period.

\section{SAMPLE DESCRIPTION}

Our sample consists of 312 bonds issued by 40 countries over the period 1986-2007. This is the set of sovereign bond offerings that was available from the Thomson Financial database as of July 2007. To our knowledge, Thomson Financial is one of the most exhaustive collections of

23. Another factor complicating predictions of what the U.S. government's position was likely to be was that Elliott's principal, Paul Singer, was a major contributor to the Republican party. So the question was whether the Bush administration's Treasury Department would be willing to file a brief that went against the interests of Singer. See Thomas (2007).

24. Our interviews suggest that this legislation took months rather than years. Interviews with officials in Belgium for a sister project suggest that the Belgian legislature removed relative quickly, in contrast to many attempts at legislation that can take years, because of the importance of demonstrating to important institutions like Euroclear that Belgium was a friendly location for them and that Elliott was an aberration (Scott and Gulati, forthcoming). 
such documents. We downloaded and read the prospectus for each of the bonds in the sample and extracted the relevant data by hand. Since the legal issues we examine arose under U.S. law, we limit our inquiry to the population of U.S.-law-issued bonds. ${ }^{25}$ As an aside, the vast majority of all sovereign bonds are issued under either U.S. or English law. Issuances governed by German or Japanese law make up but slivers of the market.

Table 1 reports the frequency of issues per year and statistics for the bonds in the sample that are shelf registrations ${ }^{26}$ and those that contain a CAC. We separate shelf registrations from other types of offerings because of the possibility that they entail unique risks to investors. ${ }^{27}$ The frequencies reported in Table 1 indicate that the sovereign bond market was thin prior to 1993. However, 13 new issues were brought to market in 1996, and the average number of new issues was slightly over 25 per year between 1996 and 2006.

The expansion in the sovereign bond market corresponds roughly to the period during which the restructurings of sovereign loans from the prior 2 decades were being concluded (Buckley 1998, 2004). The rationale for the shift from loans to bonds that is frequently given is that, after the losses the banks suffered in the 1980s, their enthusiasm for

25. U.S. law effectively means the law of the state of New York, since that is the state law that all of the bonds in our sample chose.

26. Shelf registration is authorized by Securities and Exchange Commission (SEC) rule 415 (17 C.F.R. sec. 230.415) and essentially permits issuers to separate the sometimes lengthy process of complying with the SEC registration requirements for public offerings from the actual sale of the registered securities. This permits issuers to register the security weeks and sometimes months in advance of its actual sale. Once the formal registration steps are complied with and the registration statement is effective, the issuer then places the securities "on the shelf" to await market events that allow it to reduce interest rates by discretely catching market windows. See generally Cox, Hillman, and Langevoort (2006, pp. 196-204).

27. Because speed is of the essence in catching market windows, shelf offerings customarily entail competing bids from underwriters, so there is much less time for underwriters and their counsel to perform due diligence in connection with the offerings. In addition, there is the suspicion that shelf offerings signal that the offered security is believed to be overpriced. The latter arises because the very purpose of the shelf offering is to facilitate the issuer catching favorable market windows. It is the ability to act more opportunistically in the shelf-registration context than in other types of offerings that subjects investors in securities offered pursuant to a shelf registration to a somewhat heightened risk of such opportunism. The two features mentioned, likely lower levels of diligence and likely opportunism by the issuer, may result in a market discount for shelf offerings. Compare Denis (1991, pp. 190-95), which asserts that few for-profit issuers engage in equity shelf offerings because the offerings incur substantial discounts for fear shares will be sold only when management believes they are overpriced in the market. 
Table 1. Issuances of Sovereign Debt

\begin{tabular}{|c|c|c|c|c|c|}
\hline \multirow[b]{2}{*}{ Year } & \multirow[b]{2}{*}{ Total } & \multicolumn{2}{|c|}{ Shelf Registered } & \multicolumn{2}{|c|}{$\begin{array}{l}\text { Have Collective } \\
\text { Action Clause }\end{array}$} \\
\hline & & $N$ & $\%$ & $N$ & $\%$ \\
\hline 1986 & 3 & 0 & & 0 & \\
\hline 1987 & 0 & 0 & & 0 & \\
\hline 1988 & 0 & 0 & & 0 & \\
\hline 1989 & 1 & 0 & & 0 & \\
\hline 1990 & 1 & 0 & & 0 & \\
\hline 1991 & 0 & 0 & & 0 & \\
\hline 1992 & 1 & 0 & & 0 & \\
\hline 1993 & 3 & 1 & 33 & 0 & \\
\hline 1994 & 8 & 5 & 63 & 0 & \\
\hline 1995 & 4 & 2 & 50 & 0 & \\
\hline 1996 & 13 & 8 & 62 & 0 & \\
\hline 1997 & 17 & 9 & 53 & 1 & 6 \\
\hline 1998 & 15 & 10 & 67 & 0 & \\
\hline 1999 & 22 & 17 & 77 & 1 & 5 \\
\hline 2000 & 29 & 19 & 66 & 2 & 7 \\
\hline 2001 & 33 & 22 & 67 & 3 & 9 \\
\hline 2002 & 31 & 19 & 61 & 0 & \\
\hline 2003 & 33 & 23 & 70 & 23 & 70 \\
\hline 2004 & 32 & 26 & 81 & 28 & 88 \\
\hline 2005 & 33 & 25 & 76 & 31 & 94 \\
\hline 2006 & 20 & 18 & 90 & 19 & 95 \\
\hline 2007 & 11 & 7 & 64 & 10 & 91 \\
\hline
\end{tabular}

sovereign lending diminished. The small number of outstanding bonds, however, had been largely immune from the restructurings of 1980s and early 1990s, which gave investors a level of confidence in bonds that loans did not carry (see, for example, Buchheit 2008). There was also the matter of the innovation of Brady bonds-bonds that were collateralized by U.S. treasuries and provided banks with favorable accounting treatment-that may have helped add confidence and liquidity to the sovereign bond market that emerged full-blown in the mid to late 1990s.

The data in Table 1 show that the percentage of sovereign debt issues that are shelf registered has remained relatively stable through time, averaging 68 percent per year between 1994 and 2007. In contrast, the number of sovereign issues containing CACs was virtually zero until 2003. However, 70 percent of all issues in 2003 contained a CAC, and 
306 / THE JOURNAL OF LEGAL STUdies / VOLUME 39 (1) / JANUARY 2010

this percentage increased to 92 percent for the period 2004-7. Figure 1 illustrates the composition of our sample. ${ }^{28}$

The data reported in Table 1 and illustrated in Figure 1 indicate that the bulk of the bonds in our sample were issued after 1998. The number of observations per year is more than double after 1998, relative to the yearly rate prior to 1998 . Thus, the statistical tests presented below are heavily weighted toward the 1999-2006 period. This skewing reflects the growth in the sovereign debt market in recent years, particularly in emerging economies.

\section{EMPIRICAL RESULTS}

Table 2 reports the results of our regression analysis of the spread on sovereign debt as a function of (1) the bond's rating, (2) the log of the size of the issue (amount), (3) its registration type (shelf or 144A), (4) whether the bond contains a CAC, and (5) the issue date. For each bond in the sample, we calculate the difference between the yield to maturity of the bond at its issue date and the yield to maturity of a U.S. Treasury bond with the closest time to maturity. We define this difference as the bond's spread. The vector of bond spreads is the dependent variable in all of the regressions reported in Table 2.

The results of regression (1) in Table 2 indicate that, as would be expected, the spreads on sovereign debt are significantly negatively related to the bond's Standard \& Poor's (S\&P) rating: the coefficients are monotonically related to ratings-the higher the rating, the lower the spread; the coefficients are centered around the omitted rating (BBB); and three of the four ratings' dummy variables are highly significant, with $t$-statistics of 5.0 or greater.

The results of regression (1) also indicate that spreads are negatively related to the size of the issue. This is a curious finding. If there were a downward-sloping demand curve for the bonds of a particular sovereignty, then one would expect a positive relation between spreads and amount. The more debt that is issued, the lower the price (the higher the required rate of return) and hence the greater will be the spread over U.S. treasuries. One possible interpretation of our results is that a larger issue may create a more liquid market for the country's debt, which

28. Since there are only five observations dating back to 1986 , the figure reports the data only from 1992 onward, although all of the statistical tests are performed on the entire sample. 


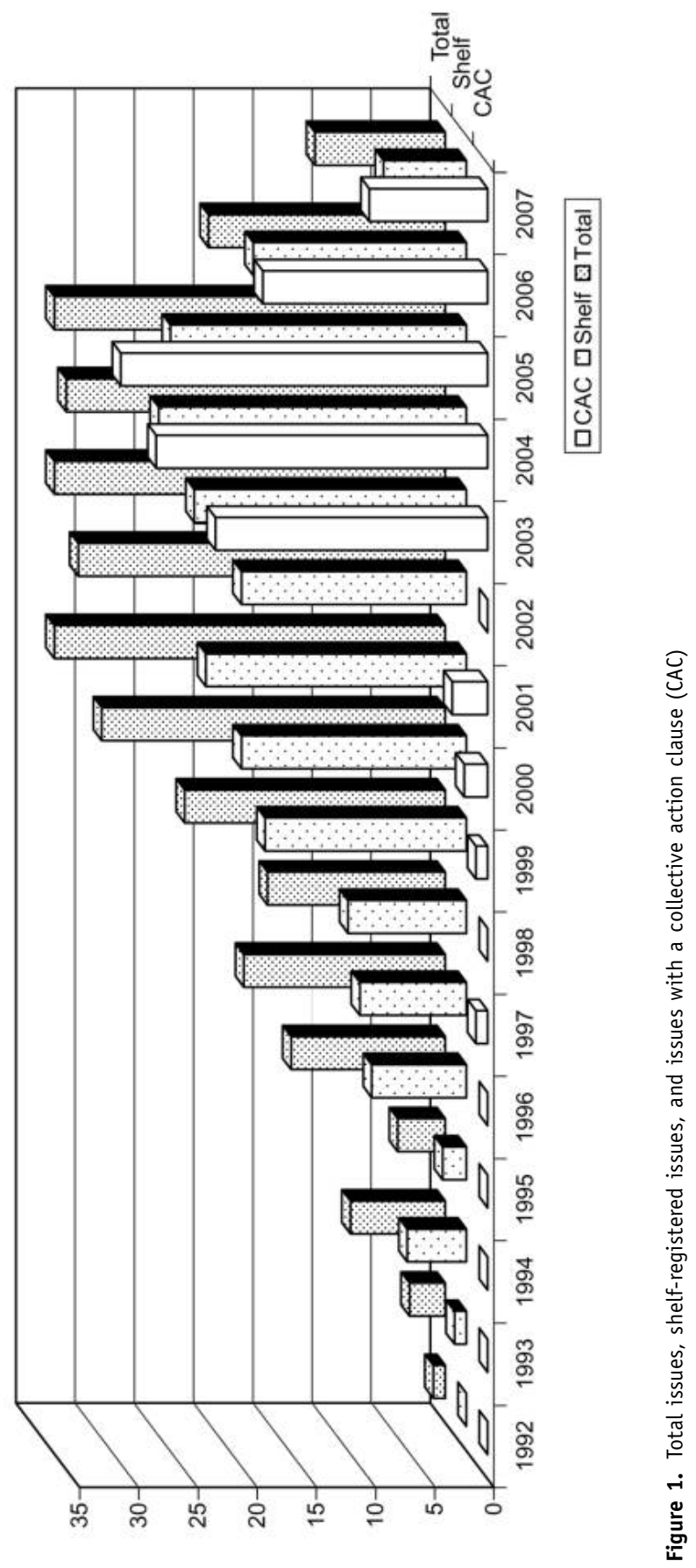




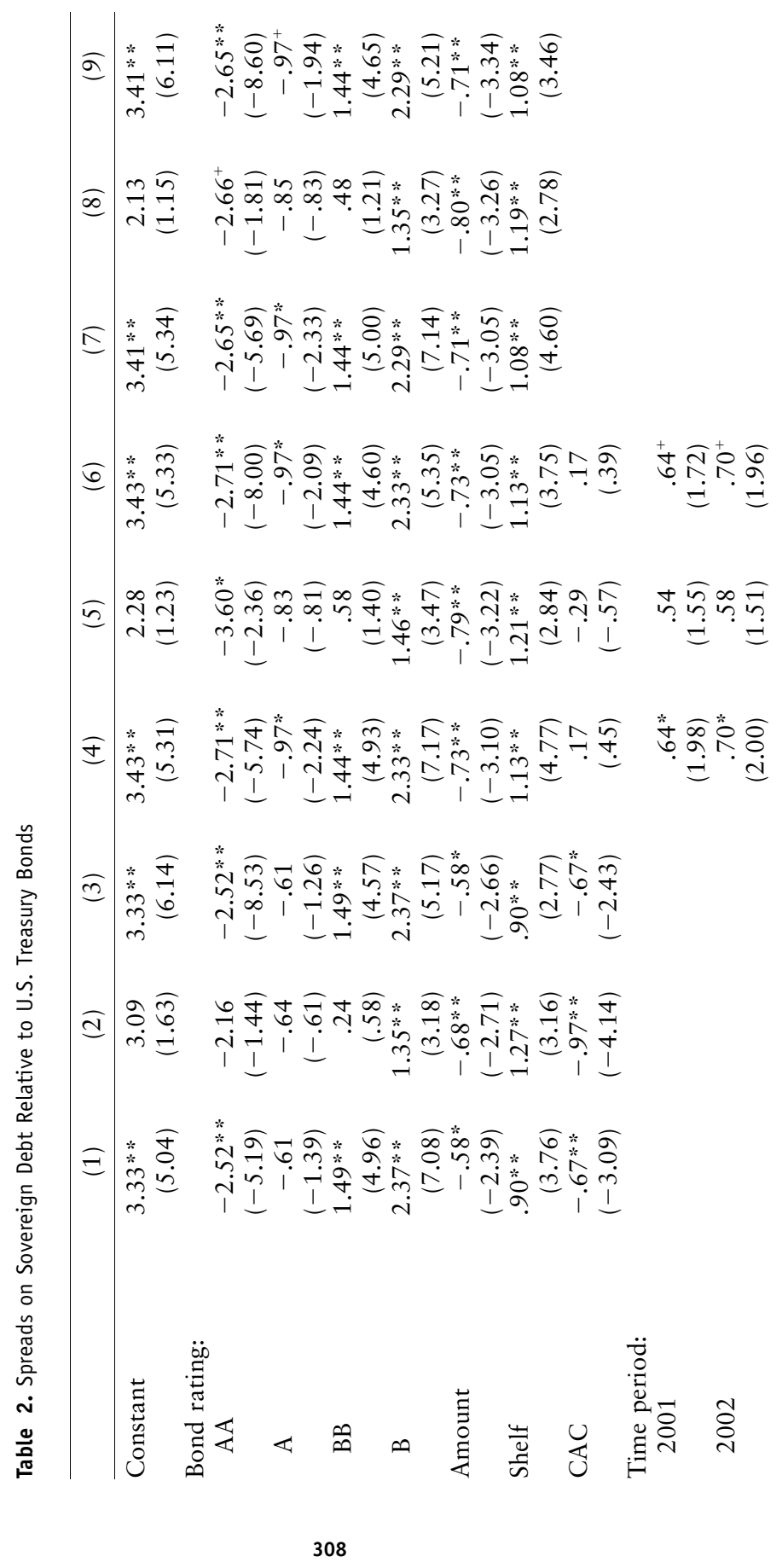




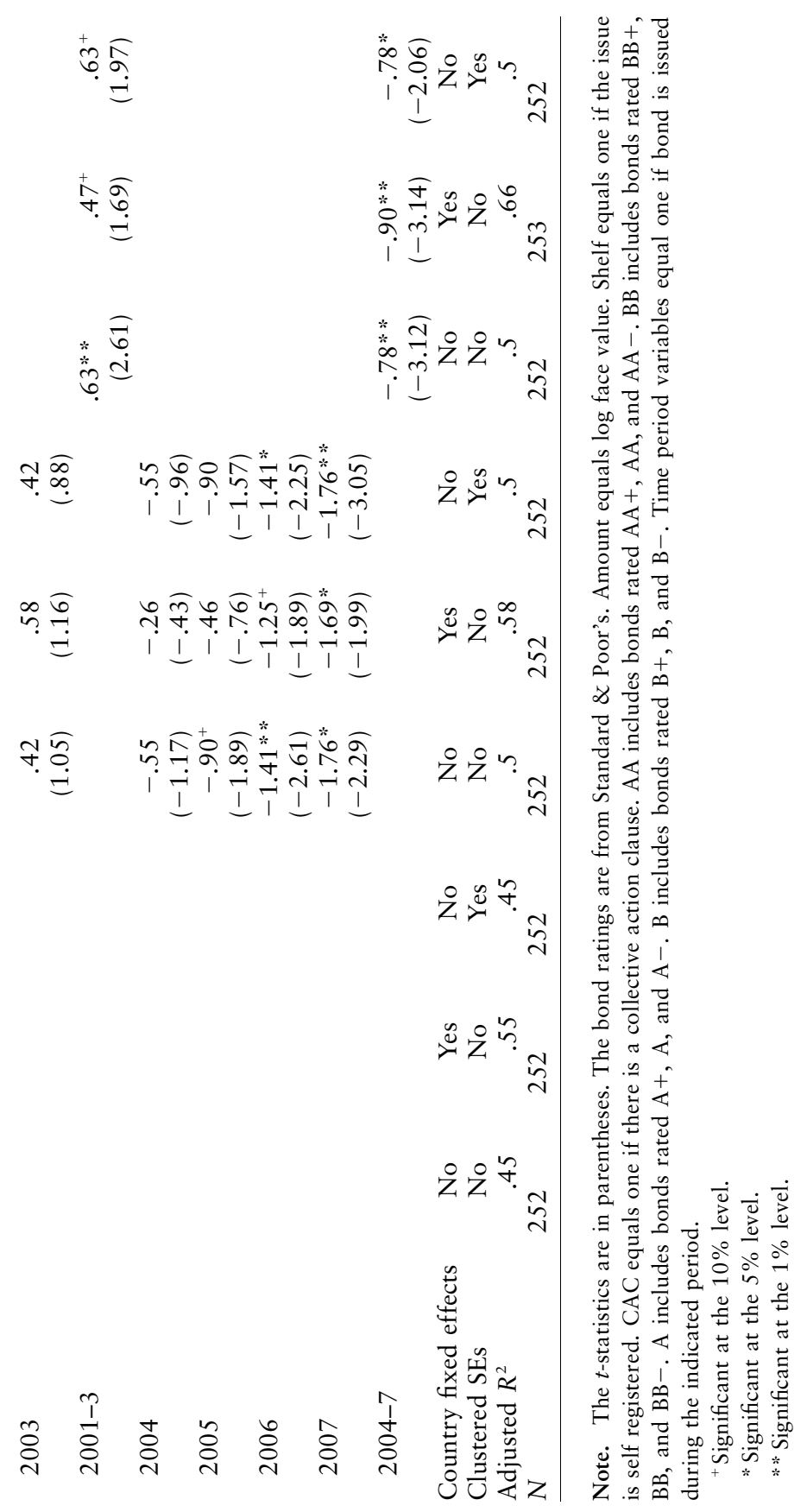

309 
would reduce its spread. In addition, there may be an element of the "too big to fail" phenomenon at play. The official sector, fearing contagion, may be more likely to step in to protect against defaults by the largest issuers.

The data reveal that shelf-registered issues command a higher spread than nonshelf issues. This is another interesting finding, since one of the presumed benefits of shelf registration is that issuers can time the market, which means that they can preregister a new issue, put the registered bonds on the shelf, and issue them when the firm, here a country, believes it to be propitious to do so. One explanation suggested in the finance literature is that market participants anticipate this incentive and respond to this adverse selection by price protecting themselves against the asymmetry of information between them and the ministries of finance in the issuing country (see Myers and Majluf [1994], which argues that the asymmetric information between firms and investors accounts for the negative reaction of the market to the announcement of a new stock issuance). Thus, they will price the bonds lower (generating a higher spread) when the country issues debt by means of a shelf registration. Finally, it may be that the quality of diligence in shelf offerings is lower than that for nonshelf offerings, because of the speed with which these offerings are taken to the market, and that the market discounts shelf offerings for this lack of due diligence. ${ }^{29}$

The results of regression (1) in Table 2 indicate that the presence of a CAC significantly reduces the spread on sovereign debt. However, recall that prior to 2003, virtually no sovereign debt had such clauses, whereas after 2003 more than 90 percent did. Thus, CAC may well be a proxy for the entire post-2003 period-a period in which spreads are lower than average. This interpretation is consistent with the results reported in subsequent regressions in which the sign of the coefficient on a CAC becomes positive and insignificantly different from zero when we add dummy variables for the post-2003 years. ${ }^{30}$

29. As demonstrated subsequently, after Elliott, there were more changes in the private offerings than in the shelf deals, which provides mild support for this conjecture. However, as we will see, there are so few changes overall that one cannot make too much of these differences.

30. Since only 75 percent of the bonds issued in 2003 had CACs, as compared with over 90 percent thereafter, we test for the cross-sectional effect of CACs in that year. We find that there is no statistical relation between the presence of a CAC and bond spreads in that year. While the spreads are predictably and consistently related to ratings, the coefficient on CAC is positive and insignificant. This sample contains 21 issues with CACs and nine without. 
Before moving on, it is important to pause and note that it has become common practice in the social science literature to adjust statistics derived from panel data for the fact that observations in the sample are not independent (Peterson 2006). For example, our initial panel consists of 312 bonds issued by 40 countries. Consequently, our sample consists of a number of bonds issued by the same country, and clearly these are not independent observations. As we discuss below, countries are reluctant to change even the language of the covenants in their debt instruments from one issue to the next. Moreover, there are certainly countryrelated risks that are not captured by the issue's S\&P rating. There are two ways to deal with the covariances inherent in panel data: one is to entertain dummy variables for each of the countries and calculate country fixed effects; the other is to cluster the estimates of the standard errors by country, which takes into account the covariance between the issues of a particular country through time. We do both.

Regression (2) in Table 2 includes 40 country dummy variables. The first thing to note is that the adjusted $R^{2}$-value increases from .45 to .55 with the inclusion of the country variables. Clearly, there are significant country-specific effects. Note also that the positive coefficient on doubleA-rated bonds (AA) and the negative coefficient on single-B-rated bonds are significant, even after controlling for country effects. Importantly, the inclusion of country fixed effects does not affect the signs or the statistical significance of the other independent variables in the modelAmount, Shelf, and CAC. Finally, regression (3) in Table 2 reports the effects of clustering standard errors at the country level. Note that this procedure does not affect the estimated coefficients-just their estimated standard errors. As can be seen, clustering standard errors has little to no effect on the statistical significance of the independent variables reported under regression (1).

Regression (4) in Table 2 includes dummy variables for the relevant years 2001-7. On the basis of the two litigation events under study, we divide the years into two periods: 2001-3, which is the post-Elliott but pre-amicus brief period, the aftermath of the shock; and 2004-7, which corresponds to the two potential antidotes to this shock: the widespread use of CACs and the announced U.S. government position in the briefs countering Elliott.

The pattern of the coefficients on the dummy variables in regression (4) across these 7 years is consistent with the predictions of the holdout analysis. All of the dummy variables for the years 2001-3 are positive, and two of the three are statistically significant. The average annual 
312 / THE JOURNAL OF LEGAL STUdies / VOLUME 39 (1) / JANUARY 2010

effect over this period is an increase of a statistically significant 63 basis points per year-see the results reported for regression (7). In contrast, all of the annual dummy variables for the years 2004-7 are negative, and three of the four are statistically significant. Moreover, as shown in regression (7), the average annual effect over this period is a decrease in the mean spread by a statistically significant 78 basis points. Thus, overall, the data indicate that the spreads on sovereign debt were abnormally high in the 2001-3 period and abnormally low in the 2004-7 period.

The results reported in regression (5) show that the inclusion of country fixed effects reduces the significance of the annual effects but does not affect their signs. Moreover, the averages for the two periods reported in regression (8) have the same signs as in regression (7) and are both statistically significant.

Table 3 reports the impact of the degree of vulnerability to the rateable payment interpretation on the spreads of sovereign debt issues. As noted at the outset, Elliott represented a legal shock because it enhanced the likelihood of holdouts and the success of engaging in a holdout strategy so that opportunistic litigation and bargaining occurred in the shadow of the newly invigorated pari passu clause. So viewed, differential price effects should exist across clauses that are worded differently and therefore present different vulnerability to litigation. The details of the variation in clauses in the market have been explored elsewhere, but broadly speaking there are three categories of clausesthose with high, medium, and low vulnerability to litigation under the rateable payments interpretation (see Scott and Gulati 2010).

The categorization we use is drawn from the writings of the leading commentators on the topic. ${ }^{31}$ The riskiest form of the clause to minority holders provides, "We will pay our debt obligations on a pro rata basis." Either that or words such as "and shall be paid as such" or "shall be discharged as such" will appear at the end of the standard clause providing for the ranking of debt claims. Italy is among the sovereigns in our data set using this type of clause. Language such as this can hardly be interpreted as other than compelling equal treatment at the moment of payment. At the opposite end of the spectrum is a clause that provides that the offered debt securities "will rank equally." Because the clause refers only to ranking (such as equal rights in any alternation of the

31. The two sources we utilize here are Buchheit (2004, p. 83) and Financial Markets Law Committee (2005). 
bond's terms) and not the act of payment, it poses a lower order of risk that the clause could be the source of a substantial holdout claim. This form of the clause is widely used and appears in offerings for Belize and Guatemala, among others. Falling in between, in the middle-risk category, are clauses appearing in offerings by Mexico and the Philippines, among others. The language in these clauses states that the debt shall "rank at least pari passu in priority of payment and in rank of security." This language was common before the Belgian court's decision in Elliott and permitted Elliott's expert to successfully argue that the words "rank" and "pay" were interchangeable so that the natural construction should be that bonds could only be paid rateably.

The results of dividing the contracts in terms of their differential vulnerability to litigation enables us to go beyond the question of whether the market reacted broadly to Elliott; our three-way classification of clauses allows discrete inquiry as to whether the market's reaction was dependent on the risk levels of the type of clause employed-a level of inquiry that has not previously been conducted with respect to bond contracts.

We see from regression (1) in Table 3 that there is an inverted $U$ shaped effect of separating the risk categories. The spreads on bonds with high litigation vulnerability and low litigation vulnerability are significantly lower than the spreads on bonds with medium litigation vulnerability (the omitted variable). Note that these relations are significant, while holding constant the bond's rating, and in regressions (4) and (5) holding constant its issue date. However, note that these relations become insignificantly different from zero when country fixed effects are added to the regression model- regressions (2), (5), and (8). The insignificance of litigation vulnerability in these regressions indicates a strong country effect, which is not surprising since, as mentioned above, countries are extremely reluctant to change the language in their bond covenants and therefore there is a high degree of correlation between countries and covenant language. Before moving on, note that the estimates of the average spread in the 2001-3 period are all significantly positive and that the estimate of average spread in the 2004-7 period are all negative and two of the three are statistically significant.

The data in Table 4 better illustrate the inverted U-shaped relation found in the data. The table reports summary statistics of the spreads for each of the three categories of litigation vulnerability: low, medium, and high. The test statistics indicate that the mean spread of the bonds in the medium category is significantly larger than the mean spread of 


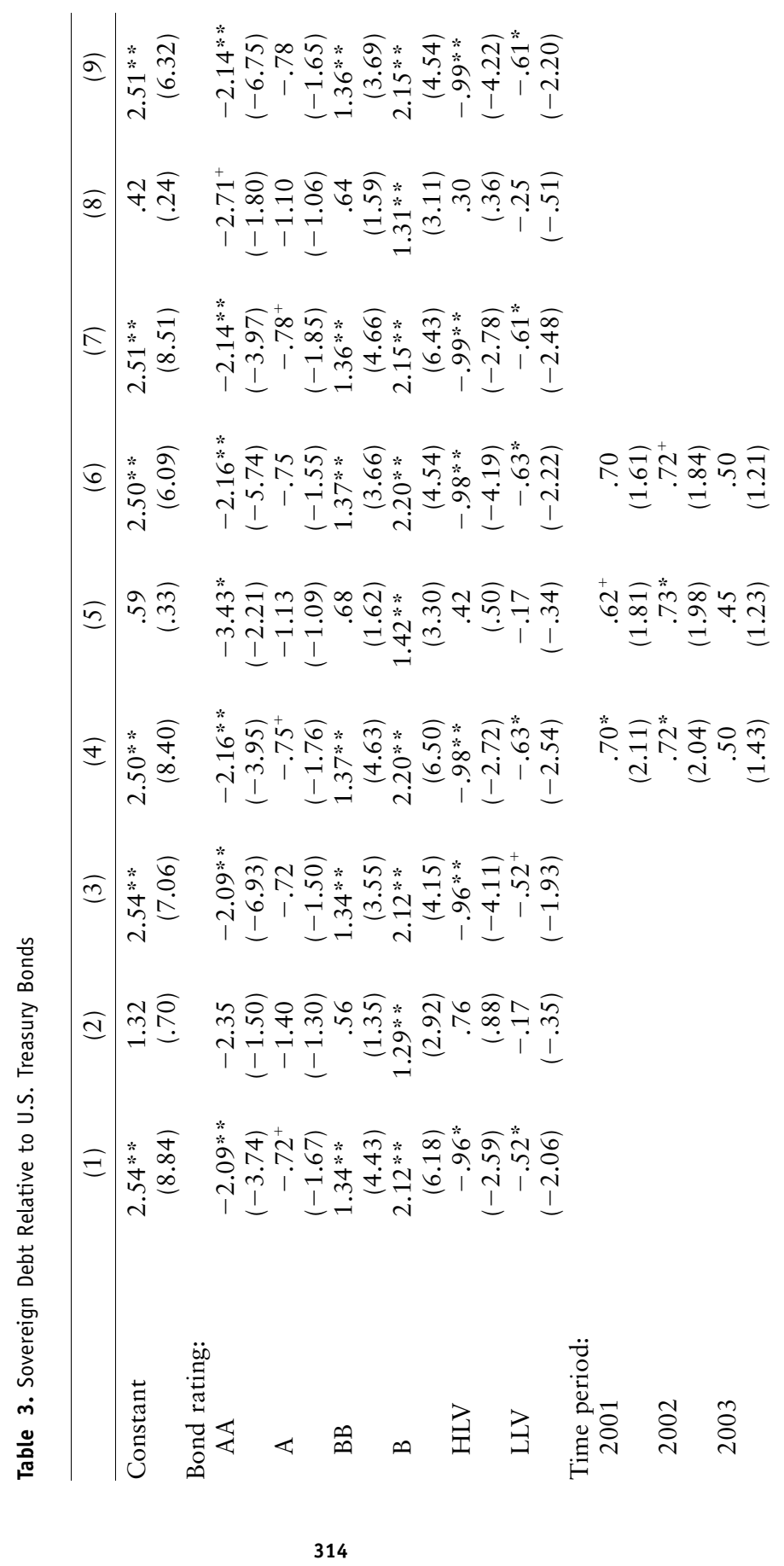




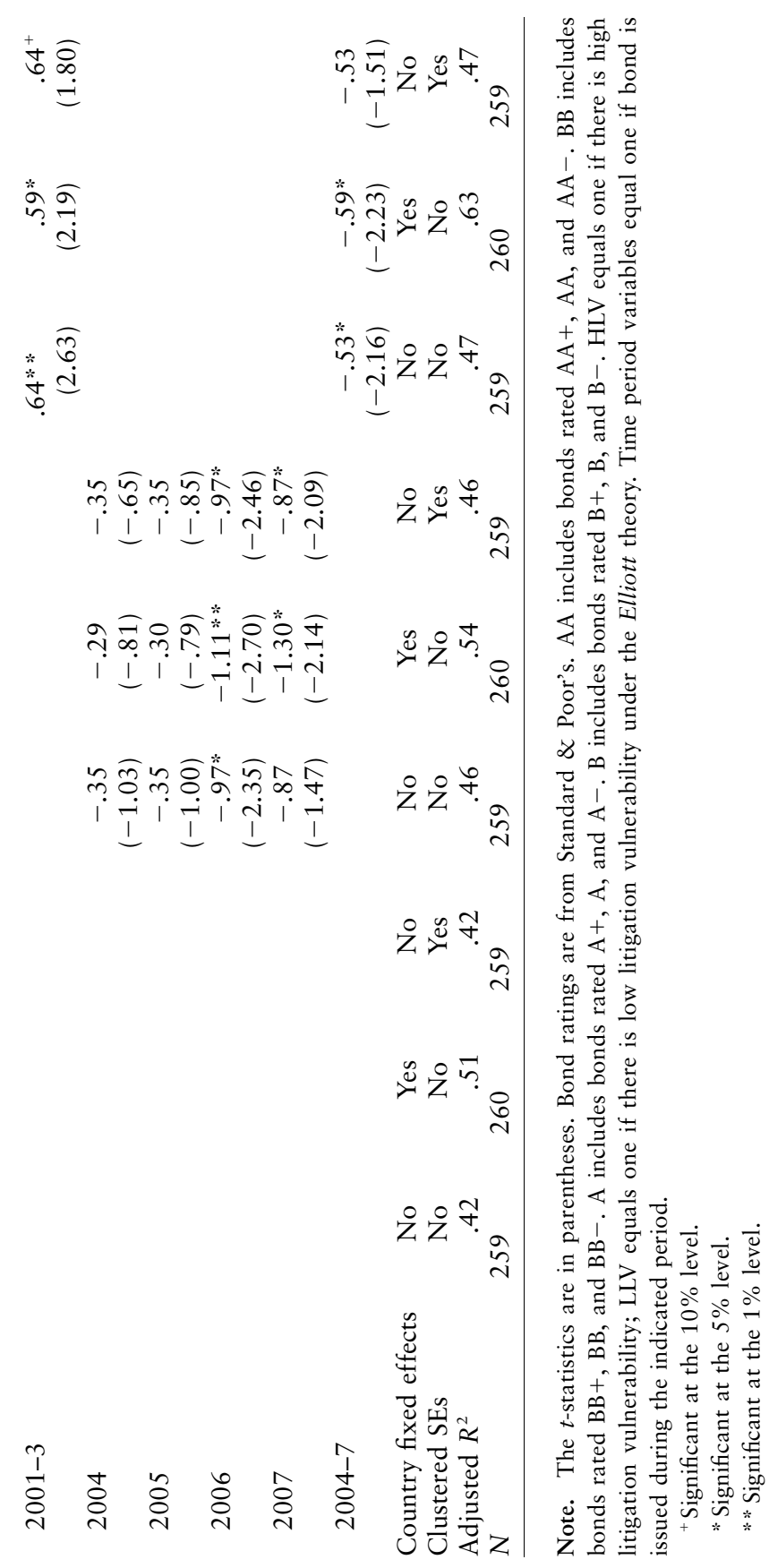

315 
316 / THE JOURNAL OF LEGAL STUdiES / VOLUME 39 (1) / JANUARY 2010

Table 4. Spreads on Sovereign Debt Relative to U.S. Treasury Bonds According to Litigation Vulnerability

\begin{tabular}{lccccc}
\hline & Low & Medium & \multicolumn{1}{c}{ High } & $\begin{array}{c}\text { Medium } \\
\text { to Low }\end{array}$ & $\begin{array}{l}\text { Medium } \\
\text { to High }\end{array}$ \\
\hline Mean & .0283 & .0387 & .0108 & .0104 & .028 \\
SD & .0147 & .0195 & .023 & .0024 & .0039 \\
$N$ & 64 & 157 & 42 &... &... \\
$t$-Statistic & $15.38 * *$ & $24.86 *$ & $3.03 * *$ & $4.30 * *$ & $7.22 * *$ \\
\hline
\end{tabular}

Note. The degree of litigation vulnerability is that under the Elliott theory.

$*$ Significant at the $1 \%$ level.

the bonds in the low category $(t=4.30)$ and larger than the mean spread of the bonds in the high category $(t=7.22)$.

There are a couple of explanations why spreads for the medium-risk pari passu clause may have increased post-Elliott while the spreads for the high- and low-risk clauses did not. The existence of the inverted $U$ shape in spreads with respect to litigation vulnerability is consistent with the commitment versus flexibility continuum that has been discussed in the literature (Mody 2004). Consistent with this view, we find that both the most risky and the least risky clauses produce positive value (lower spreads) in the eyes of investors. This occurs perhaps because, in the case of the high-risk clause, the issuer is understood to commit that it will not fail because to do so will visit upon it extraordinary transaction costs arising from the greater power the clause confers on creditors wishing to act opportunistically as holdouts. In the case of the low-risk clause, investors perhaps react positively, as they understand that this version of the pari passu contract poses the lowest likelihood of costly holdout litigation in the event of a financial restructuring. In other words, the issuer has greater flexibility if it needs to enter a restructuring.

An alternate explanation for the inverted $U$, and one that we find more plausible, reflects less faith in markets than the explanation above. Recall that prior to Elliott, the pari passu clause, while customary in sovereign debt offerings, was generally believed to have no impact on the riskiness of the offering. Our data show not only that Elliott changed this but that it increased riskiness primarily with respect to the version of the pari passu clause that was interpreted in Elliott (the medium-risk version). The uneven impact of Elliott may reflect the fact that markets did not extend Elliott's implications beyond the medium-risk clause, viewing the decision, incorrectly in our eyes, as being limited to the particular formulation before the court in Elliott. Markets therefore did 
SOVEREIGN DEBT MARKET / $\mathbf{3 1 7}$

Table 5. Frequency of Changes in the Language of Pari Passu Clauses in Sovereign Debt

\begin{tabular}{|c|c|c|c|c|c|c|c|c|}
\hline & \multicolumn{2}{|c|}{ 1986-2000 } & \multicolumn{2}{|c|}{$2001-3$} & \multicolumn{2}{|c|}{$2004-7$} & \multicolumn{2}{|c|}{ Overall } \\
\hline & Shelf & $\overline{144 \mathrm{~A}}$ & Shelf & $144 \mathrm{~A}$ & Shelf & $144 \mathrm{~A}$ & Shelf & $144 \mathrm{~A}$ \\
\hline Bonds & 73 & 20 & 61 & 27 & 77 & 19 & 211 & 66 \\
\hline Language changes & 10 & 9 & 4 & 7 & 3 & 4 & 17 & 20 \\
\hline$\%$ & 14 & 45 & 7 & 26 & 4 & 21 & 8 & 30 \\
\hline
\end{tabular}

Note. Shelf equals one if shelf registered; 144A equals one if there is private placement under Rule 144A.

not extrapolate from Elliott how its holding might impact other forms of the pari passu clause. This result is all the more understandable if one believes, as was the popular perception within the market at the time, that Elliott itself was both aberrational and sui generis (while nevertheless signaling an overall paradigm shift in holdout litigation). Our data, however, do not allow us to go beyond speculating as to possible explanations for the inverted U.

There is a puzzle here, however. When counsel for the countries that had clauses in the medium-risk category saw that there was a pricing benefit to moving to a different clause, either high risk or low risk, they should have done so. Further, even if counsel did not believe that there was a pricing benefit to moving to a different type of clause, there was still the option of doing something to reduce the risk of the rateable payments interpretation. Our empirical results show that there was a pricing penalty overall that, we conjecture, resulted from the enhanced risk of potential holdouts based on Elliott. Conceivably that penalty could have been eliminated, especially for clauses in the middle-risk range, by deleting the clause or at least adding a footnote explaining that whatever the clause meant, it did not mean what Elliott said it did. Yet Table 5 reveals that instead of drafting new language in the wake of Elliott, counsel for both the sovereigns and the underwriters ignored the decision: they did nothing. ${ }^{32}$ Instead, they waited 3 years, until 2004, when the official sector stepped in to try and provide an antidote. The data in Table 5 are reported for three separate time periods: (1) 1986-2000 (pre-Elliott), (2) 2001-3 (post-Elliott but prior to the filing of the amicus briefs), and (3) 2004-7 (post-amicus briefs). For each country in our database, we read the pari passu clauses in successive

32. We subsequently discuss the various actions that lawyers could have (should have) taken in the wake of Elliott. 
318 / THE JOURNAL OF LEGAL STUDIES / VOLUME 39 (1) / JANUARY 2010

offerings and noted whether the language changed from the previous issue. We hypothesized that changes would occur more frequently in registered public offerings than in private offerings because the former have greater liability for the sovereign issuer and its underwriters than do the latter.

The overall story implied by the results reported in Table 5 is that there were very few changes in language at all-as a general matter, the clauses hardly change. But the number of changes made, if anything, dropped after Elliott, instead of dramatically increasing. Put differently, instead of being galvanized into innovating and reforming their contracts as a result of Elliott, the lawyers appear to have become more conservative; in effect, they froze. ${ }^{33}$

As noted, we are puzzled as to why lawyers for sovereigns did not attempt to avoid the resulting rise in their clients' costs of capital by the simple expedient of either removing the pari passu clause from postElliott offerings (a course that appears relatively free of problems given the questionable role the clause would ever play, since sovereigns do not liquidate) or employing language in pari passu clauses that is less problematic.

As a check on the robustness of our empirical tests, we examine the pattern of bond ratings over the three relevant time periods. The point of this exercise is to show that our results are not being driven by changes in the distribution of bond ratings over time. Table 6 reports the distribution of the sample according S\&P bond ratings. The data show that the distribution of the ratings of sovereign bonds has remained relatively constant over the 22 years under study and virtually constant over the 2001-7 period.

\section{CONCLUSION}

Our analysis suggests that market prices adjust to unanticipated judicial events. We conjecture that the 2000 Belgian decision was a shock to the market and injected a new source of uncertainty into the pricing of these securities. We find empirical support for this conjecture. The mean spread on sovereign debt is significantly higher than the average over the preceding 9 years in the 3 years following the 2000 Belgian decision, in-

33. As an aside, there are more changes made to the clauses in the private offerings than in the public shelf deals. But the differences are not big enough to make too much of them here. 
SOVEREIGN DEBT MARKET / $\mathbf{3 1 9}$

Table 6. Distribution of Standard \& Poor's Ratings on Sovereign Debt through Time

\begin{tabular}{lrrrrrrrr}
\hline Rating & $\begin{array}{r}\text { Full } \\
\text { Sample }\end{array}$ & $\begin{array}{c}\text { \% of } \\
\text { Total }\end{array}$ & $\begin{array}{c}1986- \\
2000\end{array}$ & $\begin{array}{c}\text { \% of } \\
\text { Total }\end{array}$ & $2001-3$ & $\begin{array}{r}\% \text { of } \\
\text { Total }\end{array}$ & $2004-7$ & $\begin{array}{r}\text { \% of } \\
\text { Total }\end{array}$ \\
\hline AAA & 3 & & 3 & & & & & \\
AA & 21 & & 9 & & 8 & & 4 & \\
AA- & 2 & & & & & & 2 & \\
$\quad$ Subtotal & 23 & 7.59 & 9 & 7.96 & 8 & 8.33 & 6 & 6.38 \\
A+ & 4 & & 2 & & & & 2 & \\
A & 4 & & 1 & & & & 3 & \\
A- & 21 & & 3 & & 11 & & 7 & \\
Subtotal & 29 & 9.57 & 6 & 5.31 & 11 & 11.46 & 12 & 12.77 \\
BBB+ & 7 & & 3 & & 1 & & 3 & \\
BBB & 15 & & 5 & & 6 & & 4 & \\
BBB- & 24 & & 17 & & 5 & & 2 & \\
Subtotal & 46 & 15.18 & 25 & 22.12 & 12 & 12.5 & 9 & 9.57 \\
BB+ & 40 & & 17 & & 20 & & 3 & \\
BB & 61 & & 31 & & 10 & & 19 & \\
BB- & 32 & & 6 & & 10 & & 16 & \\
$\quad$ Subtotal & 133 & 43.89 & 54 & 47.79 & 40 & 41.67 & 38 & 40.43 \\
B+ & 22 & & 11 & & 7 & & 4 & \\
B & 35 & & 4 & & 9 & & 22 & \\
B- & 15 & & 4 & & 9 & & 3 & \\
Subtotal & 72 & 23.76 & 19 & 16.81 & 25 & 26.04 & 29 & 30.85 \\
$\quad$ Total & 303 & & 113 & & 96 & & 94 & \\
\hline
\end{tabular}

cluding in 2003, the year during which CACs began to be adopted by the sovereigns. We also find that spreads are significantly lower than the historical average in the 4 years after the filing of amicus briefs by the U.S. Treasury and the Federal Reserve calling for a New York court to reject the Belgian decision. Soon after the filing of the briefs in the U.S. case, the Belgian legislature passed a law that made it much harder for a creditor to hold out and exploit the benefit of its position in a Belgian court as Elliott had. And following on the heels of the Belgian move, an expert group of eminent lawyers in the United Kingdom, under the auspices of the Bank of England, issued a report rejecting the Elliott decision. These additional actions may have also contributed to the reduction in spreads.

Our empirical results indicate that the judicial injection of uncertainty into the meaning of crucial contract terms is priced by capital market participants in a predictable fashion. Decisions that increase the risk of repayment by sovereigns increase the yield sovereigns must pay in order to attract international capital. Decisions, such as the position announced by the U.S. government in its 2004 amici briefs, that reduced this risk reduced the cost of capital that sovereigns face. 
We should reiterate that the spread-increasing effects that we observe in the 2001-3 period may not be a function solely of Elliott but may be a function of the market's recognition that there had been a change in sovereign debt markets generally, with hedge funds beginning to pursue aggressive litigation and other strategies being undertaken for the purpose of disrupting restructurings. In other words, Elliott was perhaps more a symptom of a change rather than the change itself. ${ }^{34}$ Consistent with this, we find that the various moves taken by the official sector in the 2004-5 period to counter holdout litigation seem to have resulted in a significant spread-reducing effect. Noteworthy, however, is that we do not find spread-reducing effects from the use of CACs, which were designed to counter the broader holdout problem. A possible explanation for this might be that CACs, in the form they were initially used, were recognized to be of limited utility in countering the threat of holdout litigation. The knowledge that the U.S. government was willing to step in and file amicus briefs, by contrast, would likely have comforted the market that there was a good chance that the official sector would intervene to reduce the disruptive actions of holdouts in a sovereign restructuring.

The foregoing story challenges the dominant narrative in the sovereign debt literature, which has been to link the holdout problem to the solution of CACs. Our evidence suggests that the holdout problem was viewed as significant but perhaps that the markets did not see CACs as an effective solution. Instead, the markets drew confidence from the signals sent by the official sector when it intervened by filing amicus briefs in a key case, by passing legislation, and by sponsoring an expert report aimed at future litigation, all signals that indicate the official sector's willingness to intervene against disruptive holdout litigation. In contrast, the CAC contractual solution, which was supposed to provide a mechanism by which the markets could deal with the holdout problem on their own, appears to have had provided little confidence, at least within the time frame we examine here. ${ }^{35}$ It is possible that the utility

34. In the 2001-3 period, Elliott was followed by assertions of the rateable payments interpretation in three other cases, against the Congo, Nicaragua, and Argentina. It was in the third of those cases, against Argentina, that the U.S. government and the N.Y. Federal Reserve stepped in to give their views as amici curiae. See Scott and Gulati (2010).

35. The foregoing is not altogether surprising when one sees that CACs work only within a single bond issue. That is, a sovereign might have bonds with CACs and bonds requiring unanimous approval. In such a case, the CACs would help only to ameliorate the holdout problem with the bond that contains them. And to the extent the sovereign was not willing to treat the CAC bondholders differently than the others, the CACs would 
of this contractual solution will become more evident in the future, however, especially as the stock of old bonds without CACs diminishes (currently, only new issues contain CACs). But for now, the market appears to attach little positive value to the use of CACs.

We conclude with a conundrum: if the ambiguities arising from the Elliott decision caused an increase in the cost of sovereign debt, then why were the clauses not modified, clarified, or simply removed from future offerings more widely? Why did the official sector have to step in to provide a solution to a basic contract reform problem? The answer to these and related questions must await further research.

\section{REFERENCES}

Becker, Torbjorn, Anthony Richards, and Yungyong Thaicharoen. 2003. Bond Restructuring and Moral Hazard: Are Collective Action Clauses Costly? Journal of International Economics 61:127-61.

Berry, Charles G. 2006. "Pari Passu” Means What Now? New York Law Journal, March 6.

Bhagat, Sanjai, and Roberta Romano. 2002. Event Studies and the Law. Part I. Technique and Corporate Litigation. American Law and Economics Review 4:141-67.

Blackman, Jonathan, and Rahul Mukhi. Forthcoming. The Evolution of Modern Sovereign Debt Litigation: Vultures, Alter Egos and Other Forms. Law and Contemporary Problems.

Bradley, Michael, and Michael R. Roberts. 2004. The Structure and Pricing of Corporate Debt Covenants. Unpublished manuscript. Duke University, Fuqua School of Business, Durham, N.C. May 13. http://papers.ssrn.com/sol3/ papers.cfm?abstract_id $=466240$.

Bratton, William W. 2004. Pari Passu and a Distressed Sovereign's Choices. Emory Law Journal 53:823-67.

Bratton, William W., and Mitu Gulati. 2004. Sovereign Debt Reform and the Best Interest of Creditors. Vanderbilt Law Review 57:1-79.

Buchheit, Lee C. 2004. How to Negotiate Eurocurrency Loan Agreements. 2d ed. London: Euromoney Publications.

- 1991. The Pari Passu Clause: Sub Specie Aeternitis. International Financial Law Review, December, pp. 11-12.

- 2008. The Absence of Sufficient Temptation. Latin Finance, May 2, p. 111.

be useless (at least until the sovereign had retired all of its non-CAC bonds). The antilitigation strategies, by contrast, directly attacked the problem and potentially solved it. 
322 / THE JOURNAL OF LEGAL STUdies / VOLUME 39 (1) / JANUARY 2010

Buchheit, Lee C., and Jeremiah Pam. 2004. The Pari Passu Clause in Sovereign Debt Instruments. Emory Law Journal 53:869-922.

Buckley, Ross P. 1998. The Facilitation of the Brady Plan: Emerging Markets Debt Trading from 1989 to 1993. Fordham International Law Journal 21: 1802-89.

- 2004. Turning Loans into Bonds: Lessons for East Asia from the Latin American Brady Plan. Journal of Restructuring Finance 1:185-200.

Choi, Stephen J., and Mitu Gulati. 2004. Innovation in Boilerplate Contracts: An Empirical Examination of Sovereign Bonds. Emory Law Journal 53: 929-96.

- 2006. Contract as Statute. Michigan Law Review 104:1129-73.

Cox, James D., Robert W. Hillman, and Donald C. Langevoort. 2006. Securities Regulation: Cases and Materials. 5th ed. New York: Aspen.

Denis, David J. 1991. Shelf Registration and the Market for Seasoned Equity Offerings. Journal of Business 64:189-212.

Dixon, Liz, and David Wall. 2000. Collective Action Problems and Collective Action Clauses. Financial Stability Review 9:142-51.

Economist's View. 2006. Minneapolis Fed: John Taylor Interview. June 6. http://economistsview.typepad.com/economistsview/2006/06/minneapolis_fed .html.

Eichengreen, Barry, and Ashoka Mody. 2000a. Would Collective Action Clauses Raise Borrowing Costs? Working paper. National Bureau of Economic Research, Cambridge, Mass.

- 2000b. Would Collective Action Clauses Raise Borrowing Costs? An Update and Additional Results. Working paper. University of California, Berkeley, Department of Economics.

Eskridge Jr., William N., and Lauren E. Baer. 2008. The Continuum of Deference: Supreme Court Treatment of Agency Statutory Interpretations from Chevron to Hamdan. Georgetown Law Journal 96:1083-1226.

Financial Markets Law Committee. 2005. Issue 79_Pari Passu Clauses. London: Financial Markets Law Committee. http://www.fmlc.org/papers/fmlc79mar 2005.pdf.

Fisch, Jill E., and Caroline Gentile. 2004. Vultures or Vanguards?: The Role of Litigation in Sovereign Debt Restructuring. Emory Law Journal 53:10431113.

Gelpern, Anna, and Mitu Gulati. 2006. Public Symbol in Private Contract: A Case Study. Washington University Law Quarterly 84:1627-1715.

Gugiatti, Mark, and Anthony Richards. 2003. Do Collective Action Clauses Influence Bond Yields? New Evidence from Emerging Markets. International Finance 6:415-47.

Gulati, G. Mitu, and Kenneth N. Klee. 2001. Sovereign Piracy. Business Lawyer $56: 635-51$. 
Hagan, Sean. 2005. Designing a Legal Framework to Restructure Sovereign Debt. Georgetown Journal of International Law 36:299-402.

International Monetary Fund. 2001. Peru: Article IV Consultation and Request for Stand-by Arrangement. IMF Country Report No. 01/48. Washington, D.C.: International Monetary Fund. http://www.imf.org/external/pubs/cat/longres .cfm? sk = 3993.0.

Kahan, Marcel, and Ed Rock. 2008. Hedge Fund Activism in the Enforcement of Bondholder Rights. Northwestern University Law Review 103:281-315.

Krueger, Anne. 2001. International Financial Architecture for 2002: A New Approach to Sovereign Debt Restructuring. Speech presented at the American Enterprise Institute, Washington, D.C., November 26. http://www.imf.org/ external/np/speeches/2001/112601.htm.

Kumar, Manmohan S., and Marcus Miller. 2003. Bail-outs, Bail-ins and Bankruptcy: Evolution of the New Architecture. Pp. 343-359 in International Financial Governance under Stress: Global Structures versus National Imperatives, edited by Geoffrey R.D. Underhill and Xiaoke Liang. Cambridge: Cambridge University Press.

Lindenbaum, Eric, and Alicia Duran. 2000. Debt Restructurings: Legal Considerations (Impact of Peru's Legal Battle). Merrill Lynch Investor Report, October 30. Merrill Lynch, New York.

Lippert, Jonathan C. 2008. Vulture Funds: The Reason Why Congolese Debt May Force a Revision of the Foreign Sovereign Immunities Act. New York International Law Review 21:1-38.

Mody, Ashoka. 2004. What Is an Emerging Market? IMF Working Paper No. WP/ 04/177. International Monetary Fund, Washington, D.C. http://papers.ssrn .com/sol3/papers.cfm?abstract_id $=879002$.

Mondino, Guillermo, Esteban Fernández Medrano, and Luciano Laspina. 2003. Has Argentina Found a True Amicus? LatinSource Market Brief. LatinSource, New York. January 15. http://www.argentinien-klage.org/pari-passudiskussion/LSarMktBrief01152004.pdf.

Myers, Stuart C., and Nicholas S. Majluf. 1994. Corporate Financing and Investment Decisions When Firms Have Information That Investors Do Not Have. Journal of Financial Economics 35:99-122.

National Bank of Belgium. 2005. Financial Stability Review 2005. Brussels: National Bank of Belgium. http://www.bnb.be/doc/ts/Publications/FSR/FSR _2005_EN.pdf.

Olivares-Canal, Rodrigo. 2009. To Rank Pari Passu or Not to Rank Pari Passu: That Is the Question in Sovereign Bonds. Law and Business Review of the Americas 15:745-78.

Panizza, Ugo, Federico Sturzenegger, and Jeromin Zettelmeyer. 2009. The Economics and Law of Sovereign Debt and Default. Journal of Economic Literature 47:651-98. 
324 / THE JOURNAL OF LEGAL STUdiEs / VOLUME 39 (1) / JANUARY 2010

Peterson, Mitchell A. 2006. Estimating Standard Errors in Finance Panel Data Sets: Comparing Approaches. Review of Financial Studies 22:435-80.

Roubini, Nouriel. 2004. Private Sector Involvement in Crisis Resolution and Mechanisms for Dealing with Sovereign Debt Problems. Pp. 101-42 in Fixing Financial Crises in the $21^{\text {st }}$ Century, edited by Andrew Haldane. London: Routledge.

Salmon, Felix. 2004. Pari Passu Clause Is Threat to Markets. Euromoney, May. Scott, Hal S. 2006. Sovereign Debt Default: Cry for the United States, Not for Argentina. Working Paper No. 140. Washington Legal Foundation, Washington, D.C.

Scott, Robert, and Mitu Gulati. 2010. The Stickiness of Contract Terms: A Case Study. Unpublished manuscript. Duke University, Law School, Durham, N.C.

Sturzenegger, Federico, and Jeromin Zettelmeyer. 2007. Debt Defaults and Lessons from a Decade of Crises. Cambridge, Mass: MIT Press.

Taylor, John. 2008. Global Financial Warriors: The Untold Story of International Finance in the Post-9/11 World. New York: W.W. Norton \& Co.

Thomas Jr., Landon. 2007. Hedge Fund Chiefs, with Cash, Join Political Fray. New York Times, January 25. http://www.nytimes.com/2007/01/25/business/ 25hedge.html.

Werning, Vladmir. 2005. Argentina Debt Restructuring: Belgian Legal Reform Limits the Options for Hold Outs. J.P. Morgan Emerging Markets. February 24. J.P. Morgan, New York.

Wheeler, Christopher C., and Amir Attaran. 2003. Declawing the Vulture Funds: Rehabilitation of a Comity Defense in Sovereign Debt Litigation. Stanford Journal of International Law 39:253-84.

Wood, Philip R. 1995. Project Finance, Subordinated Debt and State Loans. London: Sweet \& Maxwell.

Zarin, Farisa. 2000. How to Sue a Sovereign: The Case of Peru. Moody's Investors Service, New York, November. 